\title{
ACCELERATED BONE FORMATION BY BIPHASIC CALCIUM PHOSPHATE WITH A NOVEL SUB-MICRON SURFACE TOPOGRAPHY
}

\author{
R. Duan ${ }^{1,2}$, L.A. van Dijk ${ }^{2,3}$, D. Barbieri ${ }^{1,2}$, F. de Groot ${ }^{2}$, H. Yuan ${ }^{2,4,5}$ and J.D. de Bruijn ${ }^{1,2,6, *}$ \\ ${ }^{1}$ Biomaterial Science and Technology, MIRA, University of Twente, Enschede, the Netherlands \\ ${ }^{2}$ Kuros Biosciences BV, Bilthoven, the Netherlands \\ ${ }^{3}$ Department of Oral and Maxillofacial Surgery, University Medical Centre Utrecht, the Netherlands \\ ${ }^{4}$ MERLN Institute for Technology Inspired Regenerative Medicine, Maastricht University, the Netherlands \\ ${ }^{5}$ College of Physical Science and Technology, Sichuan University, Chengdu, China \\ ${ }^{6}$ School of Engineering and Materials Science, Queen Mary University of London, London, UK
}

\begin{abstract}
Osteoinductive calcium phosphate $(\mathrm{CaP})$ bone grafts have equivalent performance to autografts in repairing critical-size bone defects. The osteoinductive potential of $\mathrm{CaP}$ is linked to the size of the surface topographical features. In the present study, two novel biphasic calcium phosphate (BCP) bone grafts were synthesised with either sub-micron- $\left(\mathrm{BCP}_{<\mu \mathrm{m}}\right)$ or micron-scale $\left(\mathrm{BCP}_{\mu \mathrm{m}}\right)$ needle-shaped surface topography and compared to dimensionally similar tricalcium phosphate (TCP) with grain-shaped surface structures $\left(\mathrm{TCP}_{<\mu \mathrm{m}}\right.$ and $\left.\mathrm{TCP}_{\mu \mathrm{m}}\right)$. To clarify the possible function of the surface morphology (needle-like vs. grain-like) in initiating bone formation, the four CaP test materials were physicochemically characterised and implanted for 12 weeks in the dorsal muscle of beagles. The sub-micron needle-shaped topography of $\mathrm{BCP}_{<\mu \mathrm{m}}$ triggered earlier bone formation (3-6 weeks) as compared to the grain-shaped surface topography of $\mathrm{TCP}_{<\mu \mathrm{m}}$, which formed bone at 6-9 weeks. After 12 weeks, the amount of induced bone formation in both materials was equivalent, based on histomorphometry. The micron-sized needle-shaped surface topography of $\mathrm{BCP}_{\mu \mathrm{m}}$ led to limited formation of new bone tissue, whereas its counterpart, $\mathrm{TCP}_{\mu \mathrm{m}}$ with grain-shaped surface topography, failed to trigger de novo bone formation. The relative strength of the parameters affecting CaP-driven bone induction was as follows: surface feature size > surface feature morphology > substrate chemistry. BCP materials with needleshaped sub-micron surface topography gave rise to accelerated bone formation and slower rate of resorption than a comparable TCP. These characteristics may be translated to improve bone healing in orthotopic defects.
\end{abstract}

Keywords: Osteoinduction, calcium phosphate, bone graft, surface topography, sub-micron-scale, needle crystal.

*Address for correspondence: Prof. Joost D. de Bruijn, Bronkhorstlaan 10, building 48, 3723 MB Bilthoven, the Netherlands.

Telephone number: +31 302297280 Fax number: +31 302297299 Email: j.d.debruijn@utwente.nl

Copyright policy: This article is distributed in accordance with Creative Commons Attribution Licence (http://creativecommons.org/licenses/by-sa/4.0/).

\section{Introduction}

Owing to their similarity to the inorganic component of bone, their bioactivity, biocompatibility and osteoconductivity, calcium phosphate $(\mathrm{CaP})$ materials are used clinically as bone void fillers (Habraken $e t$ al., 2016; Samavedi et al., 2013). However, because they lack osteoinductivity, their efficacy is perceived as being lower than that of the gold standard bone graft, autologous bone, in repairing critical-size bone defects (Acharya et al., 2008 ; Miyazaki et al., 2009).
Unless osteogenic agents are added to the graft material pre-implantation, osteoinduction of $\mathrm{CaP}$ bone grafts on their own is not reported until the beginning of the 1990s. Since then, initiation of bone formation by various $\mathrm{CaP}$ bone grafts with specific physicochemical properties is observed in studies of non-skeletal defect sites (e.g. subcutis and muscle) (Pollick, et al., 1995; Ripamonti, 1991; Yamasaki and Sakai, 1992; Zhang et al., 1991).

Studies comparing osteoinductive versus nonosteoinductive $\mathrm{CaP}$ in orthotopic skeletal sites 
demonstrate the benefits of osteoinductivity in bone regeneration (Duan et al., 2016). Osteoinductive CaP bone grafts not only trigger ectopic bone formation, but also enhance orthotopic bone formation by inducing osteogenic differentiation of mesenchymal stem cells (MSCs) (Davison et al., 2014a). One such osteoinductive CaP bone graft substitute has equivalent performance to an autograft, considered to be the gold standard bone graft, in repairing critical-size bone defects (Yuan et al., 2010). Having established a link between osteoinductivity and boneforming potential in orthotopic sites, researchers are focused on developing osteoinductive $\mathrm{CaP}$ bone grafts that can trigger high quality bone formation as early as possible after implantation.

Osteoinduction by $\mathrm{CaP}$ bone grafts is materialdependent and the osteoinductive potential varies with their physicochemical properties (Barradas et al., 2011; LeGeros et al., 2008), such as chemistry [i.e. the ratio hydroxyapatite (HA)/tricalcium phosphate (TCP)] (Habibovic et al., 2006), microporosity (i.e. the percentage of pores $<10 \mu \mathrm{m}$ ) (Barba et al., 2017; Chan et al., 2012) and surface architecture and geometry (Dalby et al., 2007; Davison et al., 2014a; Habibovic et al., 2005). Among those, the presence of a microporous structure is essential. Yuan et al. (1999) demonstrate that microporous HA induces ectopic bone formation, while a non-microporous HA does not. Furthermore, reducing the size of features on a microporous surface is critical for endowing $\mathrm{CaP}$ materials with osteoinductive properties. For instance, sub-micron-scale surface structured TCP can induce ectopic bone formation, while an equivalent but micron-scale surface structured alternative fails (Davison et al., 2014a; Duan et al., 2017). The influence of surface feature size is also seen in biphasic calcium phosphates (BCP), where materials with smaller grain crystals initiate ectopic bone formation, while materials with larger structures do not (Davison et al., 2015; Habibovic et al., 2005). These studies confirm that the size of surface features plays an important role in initiating bone formation by $\mathrm{CaP}$ materials in ectopic defect sites.

Currently, there is still limited knowledge as to the molecular mechanism underlying surface-topography-induced differentiation of MSCs. Geometrical features can enhance the actomyosin contractility and facilitate osteogenesis by enhancement of c-Jun N-terminal kinase and activation of the extracellular-related kinase in conjunction with elevated wingless-type (Wnt) signalling (Kilian et al., 2010). Furthermore, Zhang et al. (2017) report that the surface topography of CaPs can tune MSCs with respect to morphology, primary cilia length and transforming growth factor beta receptor (TGF $\beta R$ ) recruitment to the cilium, all of which are associated with osteogenic differentiation in vitro and bone formation in vivo.

Next to the size of features on the surface structure, the morphology is another characteristic of the surface topography which can evoke specific cellular responses in vitro (Agarwal et al., 2013; Dasgupta et al., 2014; Kolha et al., 2013; Metavarayuth et al., 2016; Ross et al., 2012). Kolhar et al. (2013) show that rod-shaped nanoparticles have higher affinity for endothelial cells in in vitro and in vivo as compared with their spherical counterparts. Similarly, Agarwal et al. (2013) report that elongated nanoparticles induce more cell adhesion and facilitate the multivalent interaction between cells and surfaces, compared to spherical nanoparticles. Dasgupta and co-workers observe that the elongated particles with higher aspect ratio induce extensive cellular uptake as compared to spherical particles with an average diameter (Dasgupta et al., 2014). Furthermore, in vitro studies indicate that surface morphology changes modulate adhesion, cytokine release and gene expression of osteogenic cells (Metavarayuth et al., 2016; Ross et al., 2012). Based on these data, the working hypothesis was that, besides the surface feature size, the morphology of the surface structure might play a crucial role in triggering bone formation in CaP materials.

The relative influence of surface feature size, surface morphology and substrate chemistry on osteoinductivity of CaP bone grafts was investigated by employing a hydrothermal treatment to obtain two needle-shaped surface structures on BCP at submicron- and micron-scale and by comparing their in vivo bone-forming potential to sub-micron and micron grain-shaped TCP counterparts.

\section{Materials and Methods}

\section{Engineering the surface morphology}

Sub-micron grain-like-surface-structured osteoinductive $\mathrm{CaP}\left(\mathrm{TCP}_{<\mu \mathrm{m}^{\prime}}\right.$ positive control) and micron grain-like-surface-structured nonosteoinductive $\mathrm{CaP}$ ( $\mathrm{TCP}_{\mu \mathrm{m}^{\prime}}$, negative control) were prepared in granular format $(1-2 \mathrm{~mm})$ as previously described (Davison et al., 2014a; Duan et al., 2016).

The two novel CaP materials were manufactured by Kuros Biosciences B.V. (Bilthoven, the Netherlands). Briefly, BCP powder was synthesised using a wet precipitation of apatite powder, followed by foaming with $\mathrm{H}_{2} \mathrm{O}_{2}$ (1\% in distilled water; Merck) and sintering for $6 \mathrm{~h}$ at either $1125^{\circ} \mathrm{C}$ or $1200{ }^{\circ} \mathrm{C}$ to obtain BCP plaques. After crushing the plaques and sieving, BCP granules (1-2 mm) were prepared and autoclaved at $135{ }^{\circ} \mathrm{C}$ for $99 \mathrm{~min}$, to form novel CaP materials with either sub-micron $\left(\mathrm{BCP}_{<\mu \mathrm{m}}\right)$ or micronscale $\left(\mathrm{BCP}_{\mu \mathrm{m}}\right)$ surface topography. All materials were sterilised with gamma irradiation (dose 25-40 kGy, Isotron Nederland B.V., Ede, the Netherlands) prior to use.

Physicochemical characterisation of CaP materials The chemical composition of the CaP materials $(n=1$ per material) was identified by X-ray diffraction 
(XRD; Miniflex II, Rigaku, Tokyo, Japan) using a scanning range of $25-45^{\circ}$, a step size of $0.01^{\circ}$ and a scanning rate of $1 \% \mathrm{~min}$. The amount of HA phase was determined by using an internal calibration system.

The surface structure of the CaP materials was analysed using a scanning electron microscope (SEM; JEOL JSM-5600, JEOL Ltd, Tokyo, Japan). The surface grain size (i.e. the vertical length crossing the centre of each grain) and the shortest axis of the needles were measured using an AxioVision LE (Carl Zeiss MicroImaging, Inc.) for at least 100 random grains or needles visualised from 10 SEM images (magnification: 5000x).

The microporosity and the specific surface area were determined by mercury intrusion porosimetry ( $n=1$ per material; Micromeritics Autopore 9600 Mercury Porosimeter, Norcross, GA, USA) with a mercury temperature of $18.36{ }^{\circ} \mathrm{C}$ and contact angle of (I) $130.00^{\circ}$, (E) $130.00^{\circ}$.

\section{In vitro assay: dissolution rate}

Calcium ion release was evaluated by soaking $0.5 \mathrm{~mL}$ of CaP granules ( $n=5$ per material) in $100 \mathrm{~mL}$ of simulated physiological saline [SPS; $0.8 \% \mathrm{NaCl}, 50 \mathrm{mM}$ 4-(2-hydroxyethyl)-1-piperazineethanesulfonic acid (HEPES), $0.4 \mathrm{mM} \mathrm{NaN}_{3} ; 37^{\circ} \mathrm{C} ; \mathrm{pH}=7.3$ ] solution for
$200 \mathrm{~min}$. While carefully stirring at $150 \times g$ to avoid the contact between the stirring bar and granules, the calcium ion concentration in SPS was recorded every minute using a calcium electrode (Metrohm, Herisau, Switzerland).

\section{In vitro assay: protein adsorption}

Protein adsorption was measured for two types of protein solutions. Sterile CaP granules $(0.2 \mathrm{~mL}$, $\mathrm{n}=5$ per material) were added to $2 \mathrm{~mL}$ of $1 \%$ volume foetal bovine serum (FBS) solution or $2 \mathrm{~mL}$ of $400 \mu \mathrm{g} / \mathrm{mL}$ bovine serum albumin (BSA) solution at $37^{\circ} \mathrm{C}$ and $5 \% \mathrm{CO}_{2}$ for 1 week. Protein adsorption was measured after $12 \mathrm{~h}, 1,4$ and $7 \mathrm{~d}$ using a micro BCA assay kit (Micro BCA Protein Assay Kit, ThermoFisher Scientific) and a spectrophotometer with an absorbance filter of $595 \mathrm{~nm}$. The amount of protein adsorbed by the samples (expressed in $\mathrm{mg} /$ $\mathrm{mL}$ for FBS and in $\mu \mathrm{g} / \mathrm{mL}$ for BSA) was estimated using internal calibration protein curves and reported per $1 \mathrm{~mL}$, which corresponded to the volume of material implanted in vivo.

\section{In vivo assay: intramuscular implantation}

All surgeries were performed following ethical approval by the local animal care committee (i.e. a

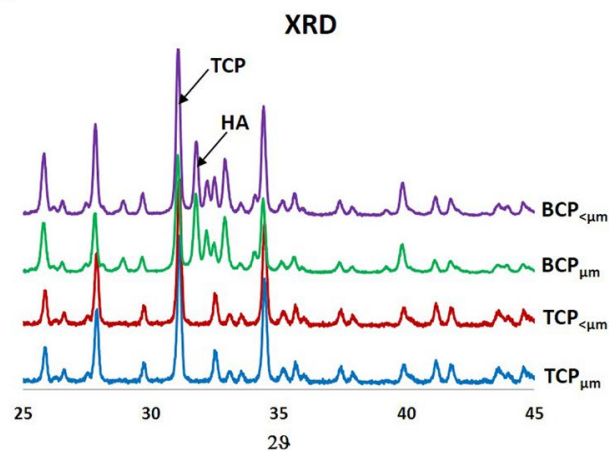

C
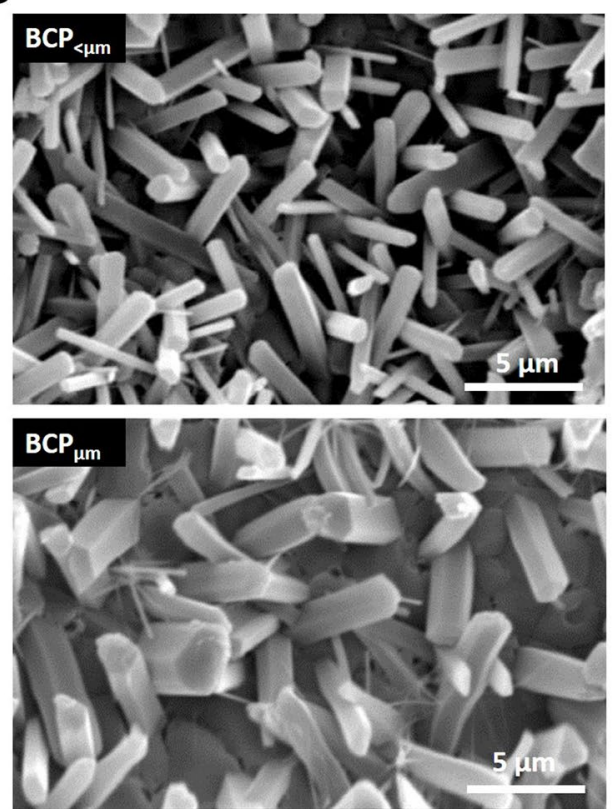

b
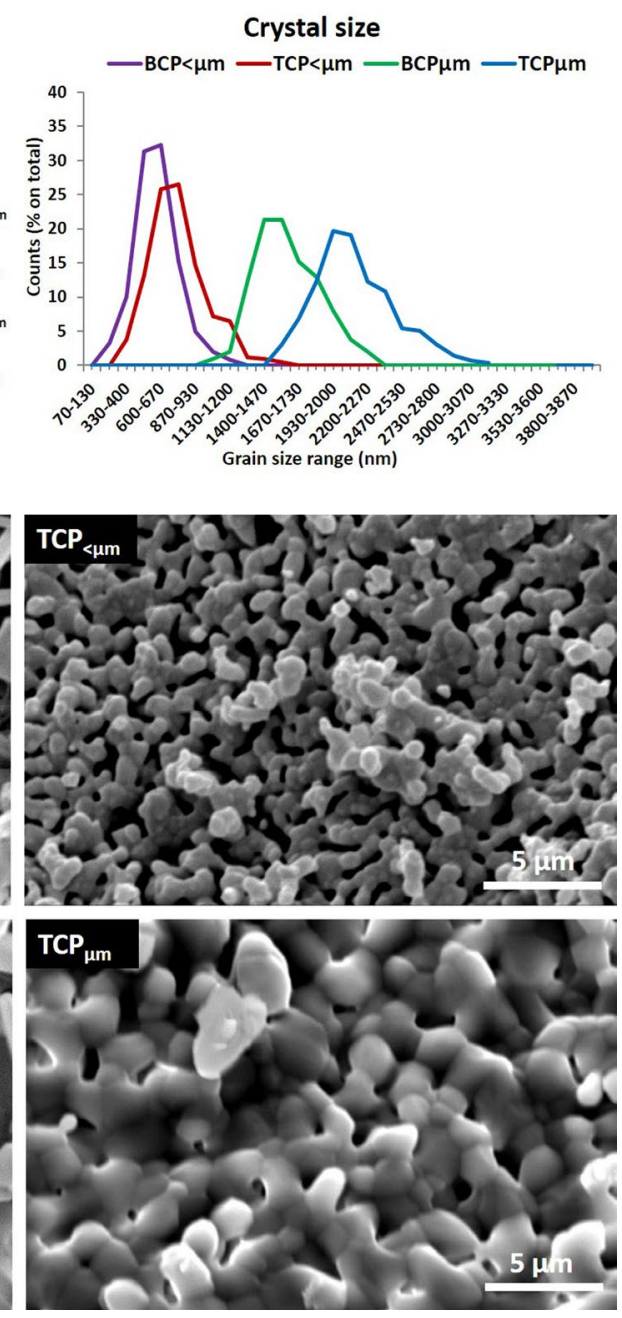

Fig. 1. Physicochemical properties of $\mathrm{CaP}$ materials. (a) XRD pattern showing the chemistry of the CaP materials; (b) distribution plots of the dimension of shortest axis of the needle of $\mathrm{BCP}_{<\mu \mathrm{m}}$ and $\mathrm{BCP}_{\mu \mathrm{m}} ;(\mathrm{c})$ SEM images showing the surface structure of the $\mathrm{CaP}$ materials. 
Table 1. Physicochemical properties of the calcium phosphate ceramic implants. ${ }^{a}$ as determined by $\mathrm{X}$-ray diffractometry; ${ }^{\mathrm{b}}$ as determined by quantitative measurements on scanning microscopic images $(5000 \times){ }^{c}$ as determined by mercury intrusion.

\begin{tabular}{|c|c|c|c|c|c|}
\hline \multicolumn{2}{|c|}{ Materials } & $\mathbf{B C P}_{<\mu \mathrm{m}}$ & $\mathrm{TCP}_{<\mu \mathrm{m}}$ & $\mathbf{B C P}_{\mu \mathrm{m}}$ & $\mathbf{T C P}_{\mu \mathrm{m}}$ \\
\hline \multirow{2}{*}{\multicolumn{2}{|c|}{ Chemistry $^{a}$}} & $25 \% \mathrm{HA} /$ & $0 \% \mathrm{HA} /$ & $22 \% \mathrm{HA} /$ & $0 \% \mathrm{HA} /$ \\
\hline & & $75 \%$ ТCP & $100 \%$ TCP & $78 \%$ ТCР & $100 \%$ TCP \\
\hline \multirow{2}{*}{\multicolumn{2}{|c|}{ Grain/needle size $(\mu \mathrm{m})^{b}$}} & $0.33-0.90$ & $0.10-1.20$ & $1.01-2.28$ & $1.30-2.45$ \\
\hline & & Median 0.60 & Median 0.70 & Median 1.52 & Median 1.96 \\
\hline \multicolumn{2}{|c|}{ Microporosity $(<10 \mu \mathrm{m})^{\mathrm{c}}$} & $9.0 \%$ & $22.0 \%$ & $5.1 \%$ & $23.0 \%$ \\
\hline \multirow{2}{*}{$\begin{array}{c}\text { Specific surface } \\
\text { area }\end{array}$} & by weight $\left(\mathrm{m}^{2} / \mathrm{g}\right)^{\mathrm{c}}$ & 2.77 & 1.71 & 1.21 & 0.79 \\
\hline & by volume $\left(\mathrm{m}^{2} / \mathrm{mL}\right)^{c}$ & 1.78 & 2.02 & 0.65 & 0.72 \\
\hline \multicolumn{2}{|c|}{$\mathrm{Ca}^{2+}$ ion released (ppm, after $200 \mathrm{~min}$ ) } & $9.5 \pm 0.8$ & $18.0 \pm 1.8$ & $5.2 \pm 0.9$ & $11.1 \pm 1.7$ \\
\hline \multirow{2}{*}{$\begin{array}{c}\text { Proteins } \\
\text { adsorbed after } \\
7 \mathrm{~d}\end{array}$} & BSA $(\mu \mathrm{g} / \mathrm{mL})$ & $1722.9 \pm 104.5$ & $1796.5 \pm 172.7$ & $786.3 \pm 48.1$ & $920.5 \pm 62.5$ \\
\hline & FBS $(\mathrm{mg} / \mathrm{mL})$ & $114.9 \pm 3.7$ & $127.6 \pm 7.2$ & $49.8 \pm 4.1$ & $60.6 \pm 3.9$ \\
\hline
\end{tabular}

the experimental animal management committee of the Sichuan province, China) and in accordance with the local laws and institutional guidelines. To evaluate their osteoinductive potential, the four CaP materials ( $n=8$ for each group) were implanted in the dorsal muscles of healthy beagles $(n=8$, 2-4 years, 10-15 kg), for 12 weeks, as described previously (Davison et al., 2014a; Duan et al., 2016). Briefly, under general anaesthesia by intravenous injection of sodium pentobarbital $(30 \mathrm{mg} / \mathrm{kg}$ body weight) and in sterile conditions, $1 \mathrm{~mL}$ of each test group was implanted into paraspinal muscle pockets created by blunt dissection. The pockets were kept isolated from each other to prevent contact between the samples. Subsequently, the muscle wound was closed with non-resorbable sutures and the skin incisions were closed layer by layer. Following the surgeries, buprenorphine (0.1 $\mathrm{mg}$ per animal) was injected intramuscularly for $2 \mathrm{~d}$ to relieve pain, while penicillin $(40 \mathrm{mg} / \mathrm{kg})$ was injected intramuscularly for 3 consecutive days to prevent infection. Animals were allowed to undertake full activity and received a normal diet immediately after surgery. To determine the time of bone formation onset, three fluorescent histological labels were utilised to indicate osteogenesis at: 1-3 weeks (calcein; green staining); 3-6 weeks (xylenol orange; red staining); 6-9 weeks (tetracycline; yellow staining). Fluorochromes were intravenously injected at 3 weeks (calcein, Sigma-Aldrich; $5 \mathrm{mg} / \mathrm{mL}, 2 \% \mathrm{NaHCO}_{3}$ solution, $\mathrm{pH}=7.41$, injection volume: $2 \mathrm{~mL} / \mathrm{kg}$ body mass), 6 weeks (xylenol orange, Sigma-Aldrich; $50 \mathrm{mg} / \mathrm{mL}$, $1 \% \mathrm{NaHCO}_{3}$ solution, $\mathrm{pH}=7.38$, injection volume:
$2 \mathrm{~mL} / \mathrm{kg}$ body mass) and 9 weeks (tetracycline, Sigma-Aldrich; $10 \mathrm{mg} / \mathrm{mL}, 0.9 \% \mathrm{NaCl}$ solution, $\mathrm{pH}=7.41$, injection volume: $2 \mathrm{~mL} / \mathrm{kg}$ body mass) after implantation.

\section{In vivo assay: implants harvest and histological processing}

12 weeks after implantation, animals were sacrificed by intravenous injection of an excessive dose of sodium pentobarbital and the implants were harvested with their surrounding soft tissue, trimmed and fixed at $4{ }^{\circ} \mathrm{C}$ in $4 \%$ buffered formaldehyde solution $(\mathrm{pH}=7.4)$ for at least 1 week. Following fixation, the samples were dehydrated using a series of gradient ethanol solutions and embedded in methyl methacrylate (MMA, K-plast, LTI, Bilthoven, the Netherlands). Consecutive histological sections (10-20 $\mu \mathrm{m})$ of non-decalcified samples were obtained by sectioning the whole samples using a diamond saw blade microtome (SP-1600, Leica). The sections were alternately not stained and stained with $1 \%$ methylene blue (Sigma-Aldrich) and $0.3 \%$ basic fuchsin (Sigma-Aldrich) after etching with acidic ethanol (Merck). The stained sections were analysed by light microscopy (Nikon Eclipse E200, Tokyo, Japan) and histomorphometry. Non-stained sections were analysed by fluorescence microscopy using a FITC Texas Red filter (Nikon) at bandpass mirror wavelengths of 510-555 $\mathrm{nm}$ and $585-665 \mathrm{~nm}$.

In vivo assay: histology and histomorphometry Stained histological sections were scanned with a slide scanner (Dimage Scan Elite 5400II, Konica Minolta 
Photo Imaging Inc.) to obtain overview images for histomorphometric analysis (i.e. the area percentage of de novo bone formation and residual material). The amount of multinucleated osteoclast-like cells was counted from 40 randomly selected histological images (magnification 20× ) and expressed as number of cells per $\mathrm{mm}^{2}$. Histomorphometric analysis was performed using Adobe Photoshop Elements 4.0 software (CS5, v12, Adobe Systems Benelux BV) as follows. First, the area encompassing the whole sample was selected as a region of interest (ROI) and the corresponding number of pixels was read as ROI. Then, the bone tissue and residual material areas were pseudo-coloured and their respective pixels were counted as B (= bone) and $\mathrm{Me}$ (= residual material), respectively. The percentage of bone in the available space was determined as B $\%=\mathrm{B} \times 100 /$ (ROI - Me), while the percentage of residual material was calculated as $\mathrm{Me} \%=\mathrm{Me} \times 100 / \mathrm{ROI}$. The percent area of material resorbed ( $\mathrm{M} \%)$ was calculated as $\mathrm{M} \%=(\mathrm{M} 0-\mathrm{Me}) \times 100 / \mathrm{M} 0$, where $\mathrm{M} 0$ was the mean pixel area of similarly embedded, sectioned and pseudo-coloured materials $(1 \mathrm{~mL}, n=8)$ that were not implanted.

Unstained histological sections were observed using fluorescence microscopy (Nikon Eclipse E600, Japan; camera Nikon FDX-35) to determine the time of onset of bone formation and material biomineralisation. The incidence (for total animals operated) of three fluorescent labels in the explants was recorded, while the number of xylenol orange staining spots (6 weeks, red colour) in the samples was counted. A quantitative index $\left(X_{\text {fluor }}\right)$, which indicated early bone formation ( $<6$ weeks), was calculated as the ratio between the total spots counted in all animals and the incidence of fluorescent labels.

\section{Statistical analysis}

Normality of the data was assessed using the ShapiroWilk test ( $p>0.05$ for normally distributed data) and statistical comparisons were carried out by one-way ANOVA and Tukey's post hoc tests, where a $p<0.05$ was considered statistically significant.

\section{Results}

\section{Physicochemical characterisation of materials}

$X$-ray diffraction analysis confirmed that the two novel $\mathrm{CaP}$ materials were $\mathrm{BCP}$ (i.e. $\mathrm{BCP}_{<\mu \mathrm{m}}$ : $25 \%$ $\mathrm{HA} / 75 \% \mathrm{TCP} ; \mathrm{BCP}_{\mu \mathrm{m}}$ : $\left.22 \% \mathrm{HA} / 78 \% \mathrm{TCP}\right)$, while both the positive and the negative controls were pure $\beta$-TCP (Fig. 1a and Table 1).

SEM imaging revealed that the two novel CaP materials had either sub-micron (median, $0.60 \mu \mathrm{m}$ ) or micron-scale needles (median, $1.52 \mu \mathrm{m}$ ) on their surface, comprising an epitaxial polygon surface

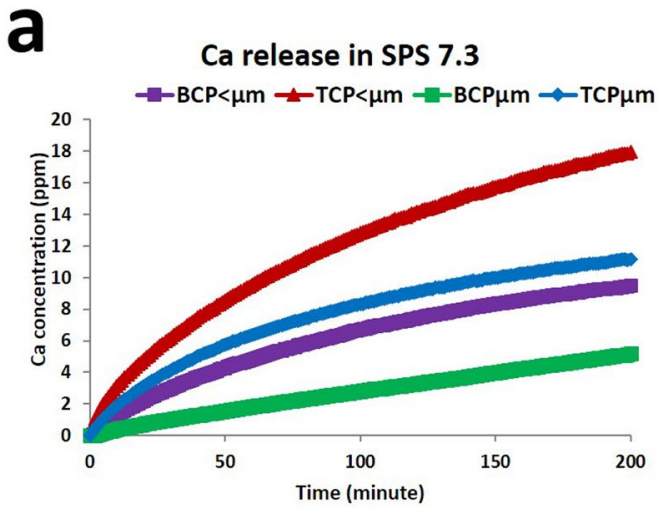

b
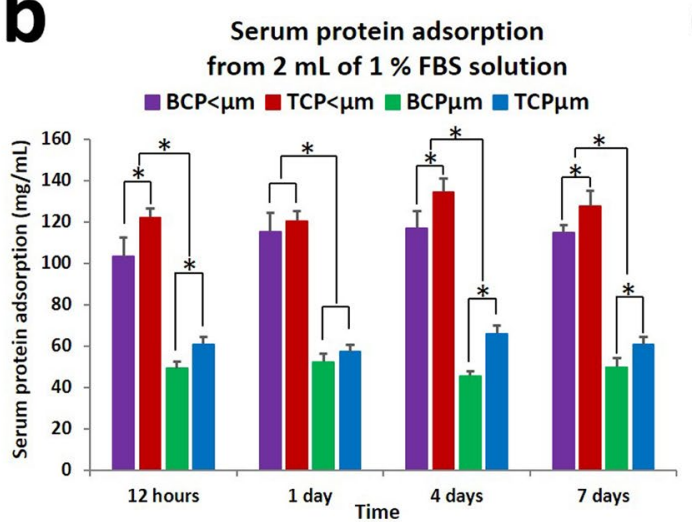

C

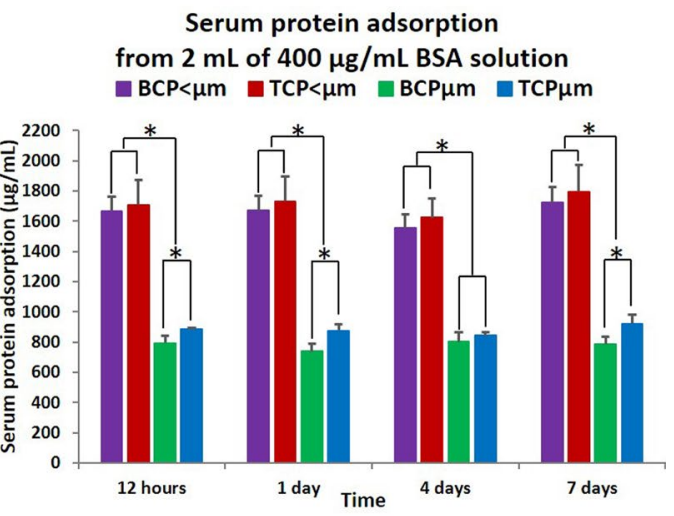

Fig. 2. In vitro evaluation of ion release and protein adsorption. (a) Calcium ion release from the materials into SPS over $200 \mathrm{~min}$; (b,c) percentage of proteins adsorbed from $2 \mathrm{~mL}$ of $1 \%$ FBS and $2 \mathrm{~mL}$ of $200 \mu \mathrm{g}$ $\mathrm{BSA} \times \mathrm{mL}^{-1}$ solution on to $0.2 \mathrm{~cm}^{3} \mathrm{CaP}$ granules for up to $7 \mathrm{~d}\left({ }^{*} p<0.05\right)$. 
structure. Both $\mathrm{TCP}_{<\mu \mathrm{m}}$ and $\mathrm{TCP}_{\mu \mathrm{m}}$ possessed grainshaped surface features, at the sub-micron-scale for $\mathrm{TCP}_{<\mu \mathrm{m}}$ (median: $0.70 \mu \mathrm{m}$ ) and micron-scale for TCP (median: $1.96 \mu \mathrm{m}$ ) (Fig. 1b,c and Table 1).

Mercury intrusion porosimetry indicated that $\mathrm{BCP}_{<\mu \mathrm{m}}$ and $\mathrm{BCP}_{\mu \mathrm{m}}$ had lower microporosity $(9.0 \%$ and $5.1 \%$ respectively), compared to $\mathrm{TCP}_{<\mu \mathrm{m}}$ and $\mathrm{TCP}_{\mu \mathrm{m}}(22.0 \%$ and $23.0 \%$, respectively). By volume, $\mathrm{TCP}_{<\mu \mathrm{m}}^{\mu \mathrm{m}}$ had a slightly larger surface area $\left(2.02 \mathrm{~m}^{2} /\right.$ $\mathrm{mL})$ than $\mathrm{BCP}_{<\mu \mathrm{m}}\left(1.78 \mathrm{~m}^{2} / \mathrm{mL}\right)$, followed by $\mathrm{TCP}_{\mu \mathrm{m}}$ $\left(0.72 \mathrm{~m}^{2} / \mathrm{mL}\right)$ and $\mathrm{BCP}_{\mu \mathrm{m}}\left(0.65 \mathrm{~m}^{2} / \mathrm{mL}\right)$ (Table 1$)$.

\section{In vitro assays: dissolution rate}

After soaking in SPS solution for $200 \mathrm{~min}$, the amount of calcium ion released from the $\mathrm{CaP}$ materials into SPS solution varied between test groups. $\mathrm{TCP}_{<\mu \mathrm{m}}$ released most calcium ions, followed by $\mathrm{TCP}_{\mu \mathrm{m}^{\prime}}$ $\mathrm{BCP}_{<\mu \mathrm{m}}$ and $\mathrm{BCP}_{\mu \mathrm{m}}$ (Fig. 2a and Table 1).

\section{In vitro assays: protein adsorption}

$\mathrm{BCP}_{<\mu \mathrm{m}}$ and $\mathrm{TCP}_{<\mu \mathrm{m}}$ adsorbed similar amount of proteins from BSA but $\mathrm{TCP}_{<\mu \mathrm{m}}$ absorbed more protein from FBS (Fig. 2b,c). Both TCP ${ }_{\mu \mathrm{m}}$ and $\mathrm{BCP}_{\mu \mathrm{m}}$ absorbed significantly less protein from BSA and FBS than their sub-micron counterpart test materials (Table 1).

\section{Histology and histomorphometry}

After 12 weeks of intramuscular implantation, all explants were encapsulated by a thin layer of connective tissue, which also infiltrated the $\mathrm{CaP}$ materials. De novo bone formation was observed in 8 out of $8 \mathrm{BCP}_{<\mu \mathrm{m}}$ and $\mathrm{TCP}_{<\mu \mathrm{m}}$ (positive control) explants, 7 out of $8 \mathrm{BCP}_{\mu \mathrm{m}}$ explants and 0 out of 8 $\mathrm{TCP}_{\mu \mathrm{m}}$ (negative control) explants (Fig. 3a, Table 2). Osteoids with a seam of cuboidal osteoblasts lying on their outer surface as well as osteocytes entrapped in lacunae of lamellar and woven bone were clearly observed in $\mathrm{BCP}_{<\mu \mathrm{m}}, \mathrm{TCP}_{<\mu \mathrm{m}}$ and $\mathrm{BCP}_{\mu \mathrm{m}}$ explants (Fig. $3 \mathbf{b}, \mathbf{c})$. In addition, multinucleated osteoclast-like cells phagocytising small fragments of $\mathrm{CaP}$ were localised on the surface of the test $\mathrm{CaP}$ material for $\mathrm{BCP}_{<\mu \mathrm{m}}\left(22 \pm 7\right.$ cells $\left./ \mathrm{mm}^{2}\right)$ and $\mathrm{TCP}_{<\mu \mathrm{m}}(14 \pm 6$ cells/ $\mathrm{mm}^{2}$ ) groups. In contrast, the multinucleated osteoclast-like cells were sporadically present in $\mathrm{BCP}_{\mu \mathrm{m}}\left(4 \pm 3\right.$ cells $\left./ \mathrm{mm}^{2}\right)$ and scarcely present in any of the non-osteoinductive TCP ${ }_{u m}\left(0\right.$ cells $\left./ \mathrm{mm}^{2}\right)$ (Fig. 4$)$. More condensed collagen fibrils, bone marrow and blood vessels were observed in $\mathrm{BCP}_{<\mu \mathrm{m}}$ and $\mathrm{TCP}_{<\mu \mathrm{m}}$ implants, which were less compact in $\mathrm{BCP}_{\mu \mathrm{m}}$. Looser connective tissue, with very limited presence of blood vessels, was detected in $\mathrm{TCP}_{\mu \mathrm{m}}$.

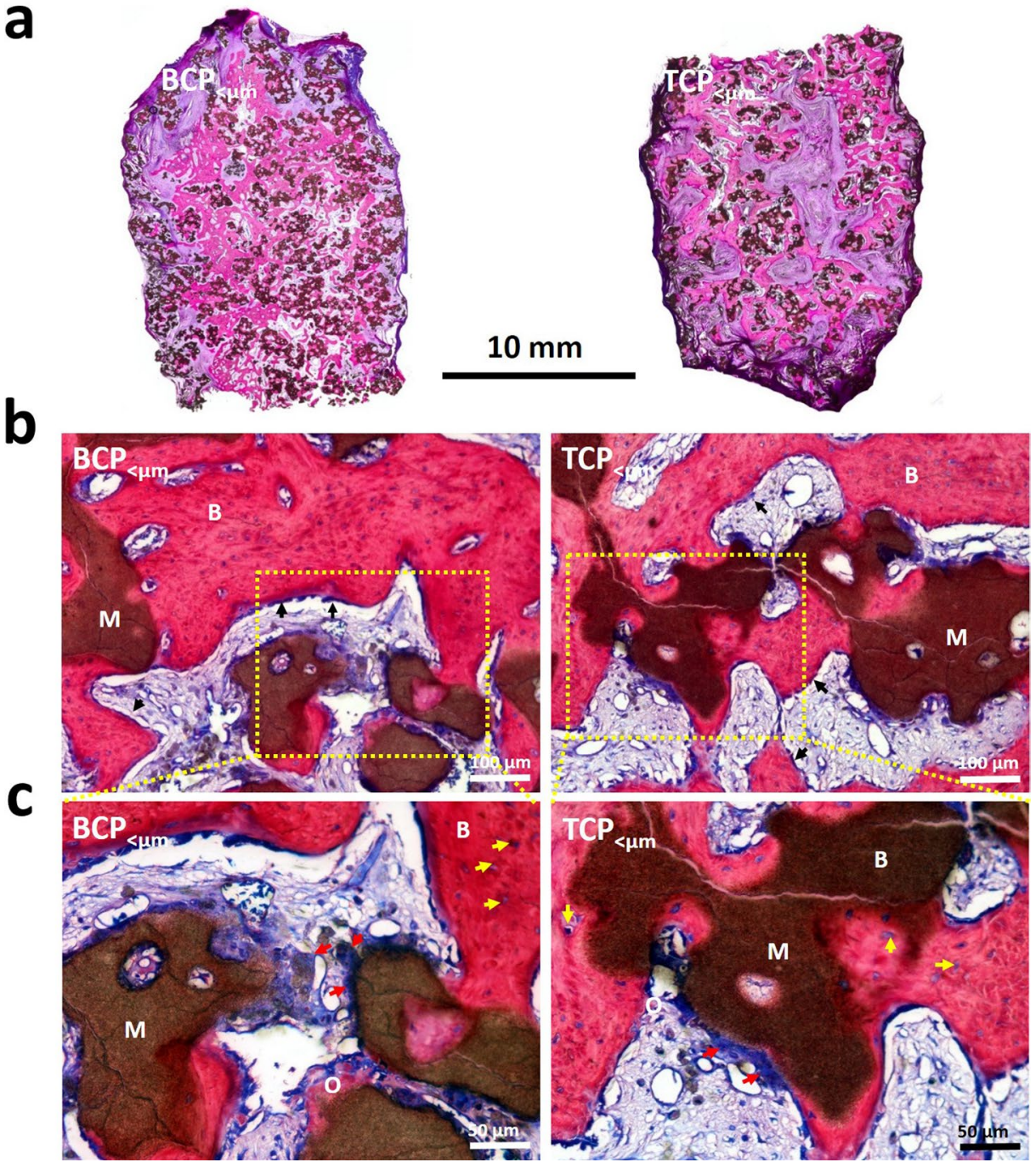

Fig. 3. Histological images of $\mathrm{BCP}_{<\mu \mathrm{m}}$ and $\mathrm{TCP}_{<\mu \mathrm{m}}$ after 12 weeks of implantation. (a) Histological overviews showing the bone regeneration and material resorption of CaP materials; $(\mathbf{b}, \mathbf{c})$ detailed histological images showing bone formation and remodelling as well as degradation of CaP substrates (non-decalcified sections stained with methylene blue and basic fuchsin, B: bone; M: material; black arrow: osteoblast; yellow arrow: osteocytes; red arrow: phagocytic cells). 
Table 2. A summary of the explants from muscle of beagles after 12 weeks.

\begin{tabular}{|c|c|c|c|c|c|}
\hline \multicolumn{2}{|c|}{ Explants } & $\mathbf{B C P}_{<\mu \mathrm{m}}$ & $\mathbf{T C P}_{<\mu \mathrm{m}}$ & $\mathbf{B C P}_{\mu \mathrm{m}}$ & $\mathbf{T C P}_{\mu \mathrm{m}}$ \\
\hline \multirow{2}{*}{ 3 weeks (green color) } & Calcein incidence & $8 / 8$ & $8 / 8$ & $8 / 8$ & $0 / 8$ \\
\hline \multirow{2}{*}{ 6 weeks (red color) } & Xylenol orange incidence & $5 / 8$ & $2 / 8$ & $0 / 8$ & $0 / 8$ \\
\cline { 2 - 6 } & $\sum$ (spots) & 21 & 2 & 0 & 0 \\
\cline { 2 - 6 } & $\mathrm{X}_{\text {fluor }}$ & 4.2 & 1.0 & 0 & 0 \\
\hline \multirow{2}{*}{ 9 weeks (yellow color) } & Tetracycline incidence & $8 / 8$ & $8 / 8$ & $0 / 8$ & $0 / 8$ \\
\hline \multirow{2}{*}{$\mathbf{1 2}$ weeks } & Bone incidence & $8 / 8$ & $8 / 8$ & $7 / 8$ & $0 / 8$ \\
\cline { 2 - 6 } & Bone area in available space (B \%) & $24.5 \pm 4.3$ & $23.9 \pm 6.3$ & $2.1 \pm 1.7$ & 0 \\
\cline { 2 - 6 } & Material resorption (\%) & $28.1 \pm 4.1$ & $53.8 \pm 5.7$ & $9.3 \pm 2.4$ & $4.7 \pm 2.1$ \\
\hline
\end{tabular}

Under fluorescent microscopy (Fig. 5, Table 2), xylenol orange was detected in 5 out of $8 \mathrm{BCP}_{<\mu \mathrm{m}}$ and in 2 out of 8 of $\mathrm{TCP}_{<\mu m}$ explants. Calcein and tetracycline were observed in all the $\mathrm{BCP}_{<\mu \mathrm{m}}$ and $\mathrm{TCP}_{<\mu \mathrm{m}}$ explants. Only calcein was found in $\mathrm{BCP}_{\mu \mathrm{m}}$ explants and no fluorescent signal was measured in any of the TCP ${ }_{\mu m}$ explants. Xylenol orange was detected in the bone inside the $\mathrm{BCP}_{<\mu \mathrm{m}}$ implants, indicating that the marked bone formed between 3 and 6 weeks post-implantation. Whereas, tetracycline was the predominant fluorophore observed in the bone formed in $\mathrm{TCP}_{<\mu \mathrm{m}^{\prime}}$ revealing that it formed between 6 and 9 weeks. No xylenol orange or tetracycline fluorophores were detected in $\mathrm{BCP}_{\mu m^{\prime}}$ indicating no bone formation in these defects after 9 weeks post-implantation. These qualitative observations were corroborated by the quantitative data. In fact, the $X_{\text {fluor }}$ index and the xylenol orange incidence (Table 2) indicated that much more bone was formed between week 3 and week 6 in $\mathrm{BCP}_{<\mu \mathrm{m}}$ as compared to the positive control $\left(\mathrm{TCP}_{<\mu \mathrm{m}}\right)$. In sharp contrast, $\mathrm{BCP}_{\mu \mathrm{m}}$ and $\mathrm{TCP}_{\mu \mathrm{m}}$ showed no xylenol orange fluorescence (Table 2).

$\mathrm{BCP}_{<\mu \mathrm{m}}$ led to faster bone formation but, by the time of sacrifice at 12 weeks, $\mathrm{BCP}_{<\mu \mathrm{m}}$ and the positive control, $\mathrm{TCP}_{<\mu m^{\prime}}$ led to similar amounts of bone tissue, as measured by histomorphometry: $24.5 \pm 4.3 \%$ and $23.9 \pm 6.3 \%$, respectively, followed by $\mathrm{BCP}_{\mu \mathrm{m}}(2.1 \pm 1.7 \%)$. No bone formed in $\mathrm{TCP}_{\mu \mathrm{m}}$ (Fig. 6a). In addition, the percentage area of resorbed material (by histomorphometry) profoundly varied among the four materials: $\mathrm{TCP}_{<\mu m}$ underwent the most material resorption $(53.8 \pm 5.7 \%)$, followed by $\mathrm{BCP}_{<\mu \mathrm{m}}(28.1 \pm 4.1 \%), \mathrm{BCP}_{\mu \mathrm{m}}(9.3 \pm 2.4 \%)$ and $\mathrm{TCP}_{\mu \mathrm{m}}$ $(4.7 \pm 2.1 \%)$ (Fig. 6b).

\section{Discussion}

A hydrothermal treatment was employed to promote the growth of a layer of epitaxial crystals on the surface of BCP materials, leading to a novel needle-shaped surface topography. By adjusting the sintering temperature (i.e. $1125^{\circ} \mathrm{C}$ or $1200^{\circ} \mathrm{C}$ ) of the BCP materials, needle-like crystals at either the sub-micron or micron-scale were achieved (Fig. 1). In vivo, the novel $\mathrm{CaP}$ with sub-micron needle-shaped topography $\left(\mathrm{BCP}_{<\mu \mathrm{m}}\right)$ triggered earlier bone formation (3-6 weeks) as compared to TCP with a sub-micron grain-shaped surface topography $\left(\mathrm{TCP}_{<\mu \mathrm{m}}\right)$, which mainly formed bone at 6-9 weeks (Fig. 5). By 12 weeks post-implantation, the amount of bone formed by the positive control, $\mathrm{TCP}_{<\mu \mathrm{m}^{\prime}}$ was equivalent to the amount formed by the novel needle-like surface topography of $\mathrm{BCP}_{<\mu \mathrm{m}}$ (Fig. 6a). Similarly, $\mathrm{BCP}_{\mu \mathrm{m}}$ with a micron-scale needle-shaped surface topography underwent in vivo biomineralisation and gave rise to ectopic bone formation, while its counterpart, $\mathrm{TCP}_{\mu \mathrm{m}^{\prime}}$ with micron-scaled grain-like crystals did not (Fig. 5,6a).

In agreement with previous reports, the size of the surface structure greatly affected the osteoinductive potential of CaP materials (Davison et al., 2014a; Duan et al., 2016; Duan et al., 2017; Habibovic et al., 2005; Yuan et al., 2010; meeting abstract: Duan et al., ORS 2018 Annual Meeting: 0056). As expected, inductive bone formation occurred in larger amounts for the sub-micron surface structured $\mathrm{BCP}_{<\mu \mathrm{m}}$ and $\mathrm{TCP}_{<\mu \mathrm{m}}$ grafts but very limited bone formed in $\mathrm{BCP}_{\mu \mathrm{m}}$ and no bone formed in $\mathrm{TCP}_{\mu \mathrm{m}}$, both having a micronscale surface topography (Fig. 3, 4, 5 and 6). The strength of the observed effect suggested that the 
scale of topography influenced osteoinductivity independently of chemistry and surface morphology. Based on the available data for grain size, surface area and protein adsorption for $\mathrm{BCP}_{<\mu \mathrm{m}}$ and $\mathrm{TCP}_{<\mu \mathrm{m}}$ versus $\mathrm{BCP}_{\mu \mathrm{m}}$ and $\mathrm{TCP}_{\mu \mathrm{m}^{\prime}}$, this could either be due to a direct or an indirect effect of the smaller surface feature size on bone formation.

Could the specific surface topography exert a direct effect on bone formation by affecting attached cells? In the absence of chemical factors, surface topographies ranging from nano- to micronscale evoke specific cell attachment, orientation, proliferation and guide cell differentiation towards various lineages (Abagnale et al., 2015; Dupont et al., 2011; Kolind et al., 2014; Mitragotr and Lahann, 2009; Oh et al., 2009; Phadke et al.,2013). At the micron-scale, surface structure enhances adipogenic differentiation of MSCs, while sub-micron-scaled surface structures favours osteogenic differentiation (Abagnale et al., 2015; Davison et al., 2014a; Duan et al., 2016). Submicron surface topographies can preferentially direct early wound healing toward the bone-forming pathway by influencing macrophage polarisation (Italiani and Boraschi, 2014; Loi et al., 2016; Spiller et al., 2015; meeting abstract: Duan et al., ORS 2018
Annual Meeting: 0056). The role of macrophages as either mediators of a pro-inflammatory response or mediating a wound-healing and angiogenic response is well understood (Italiani and Boraschi, 2014). The key to successful bone healing, that is to promote osteogenesis and avoid the formation of scar tissue, is to tip the balance of wound healing toward the M2, or deactivated, macrophage response following an initial phase of inflammation (Loi et al., 2016; Spiller et al., 2015). CaP materials with a sub-micron surface topography direct the transition of macrophages to the M2 phenotype, as shown by the larger production of TGF- $\beta$ and chemokine (C-C motif) ligand 18 (CCL18) from cells cultured on $\mathrm{CaP}$ with sub-micron surface structures (meeting abstract: Duan et al., ORS 2018 Annual Meeting: 0056). At the same time, CaP materials with micron surface topography display more M1 macrophages formation, as indicated by an enhanced TNF- $\alpha$ and IL-1 $\beta$ secretion (meeting abstract: Duan et al., ORS 2018 Annual Meeting: 0056). The conditioned media harvested from THP-1 cells cultured on CaP with submicron surface topography enhance tube formation by human umbilical vein endothelial cells (HUVECs) in vitro. Furthermore, sub-micron surface topography

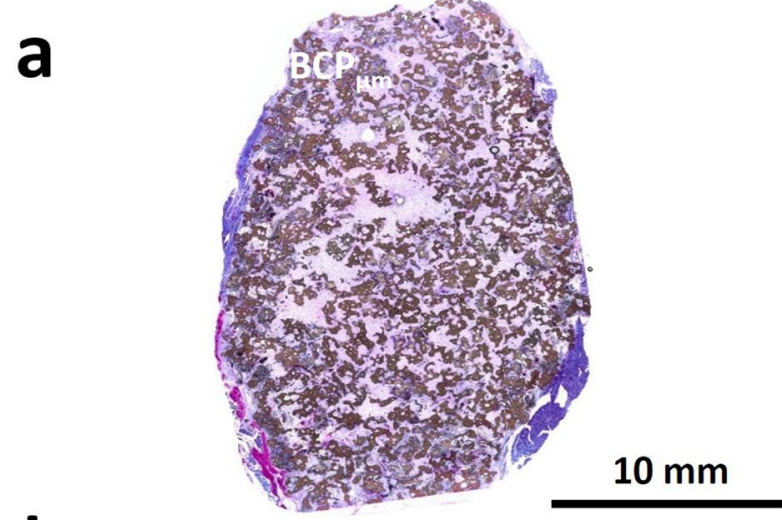

\section{b}

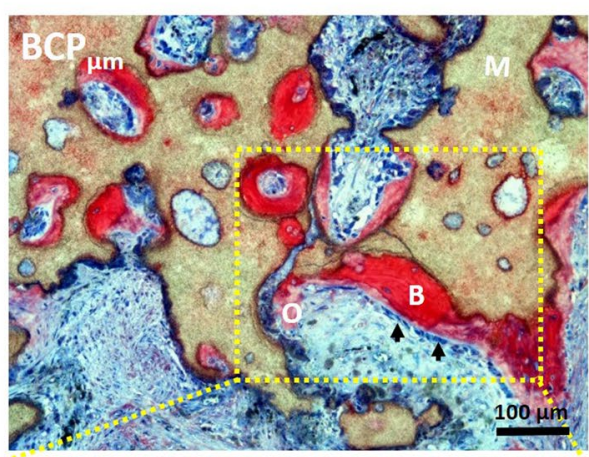

C

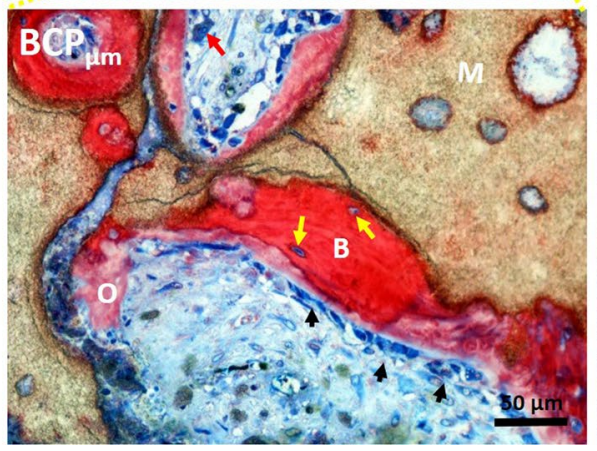

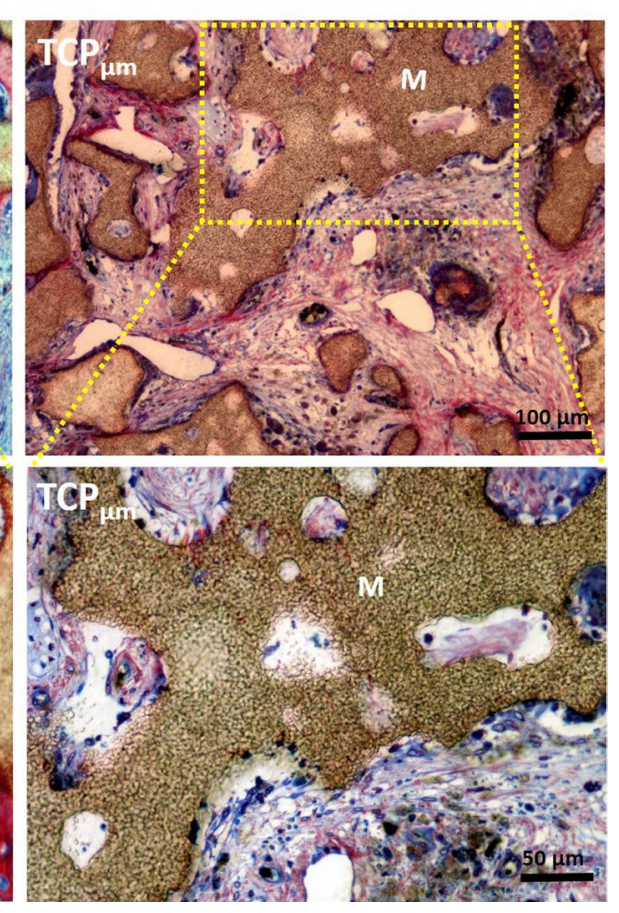

Fig. 4. Histological images of $\mathrm{BCP}_{\mu \mathrm{m}}$ and TCP $_{\mu \mathrm{m}}$ after 12 weeks of implantation. (a) Histological overviews showing the bone regeneration and material resorption of CaP materials; $(\mathbf{b}, \mathbf{c})$ detailed histological images showing bone formation and remodelling as well as degradation of $\mathrm{CaP}$ substrates (nondecalcified sections stained with methylene blue and basic fuchsin, B: bone; M: material; black arrow: osteoblast; yellow arrow: osteocytes; red arrow: phagocytic cells). 

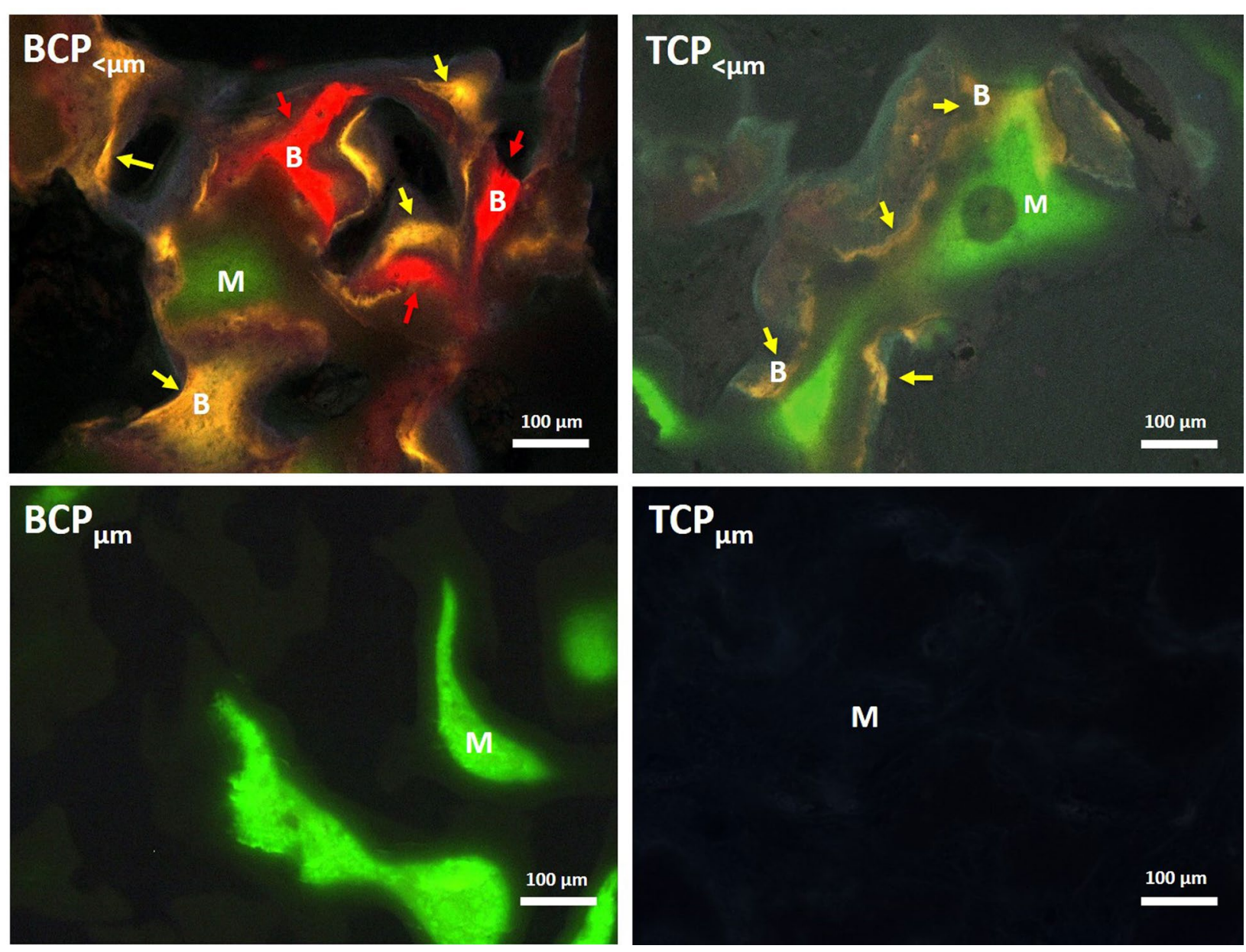

Fig. 5. Fluorescent images showing the mineralization of materials and onset time of bone formation within $\mathrm{CaP}$ materials intramuscularly implanted in dogs for 12 weeks. Green, calcein, 3 weeks; red, xylenol orange, 6 weeks; yellow, tetracycline, 9 weeks; M: materials; B: bone tissue; red arrow: bone tissue stained with xylenol orange; yellow arrow: bone tissue stained with tetracycline.
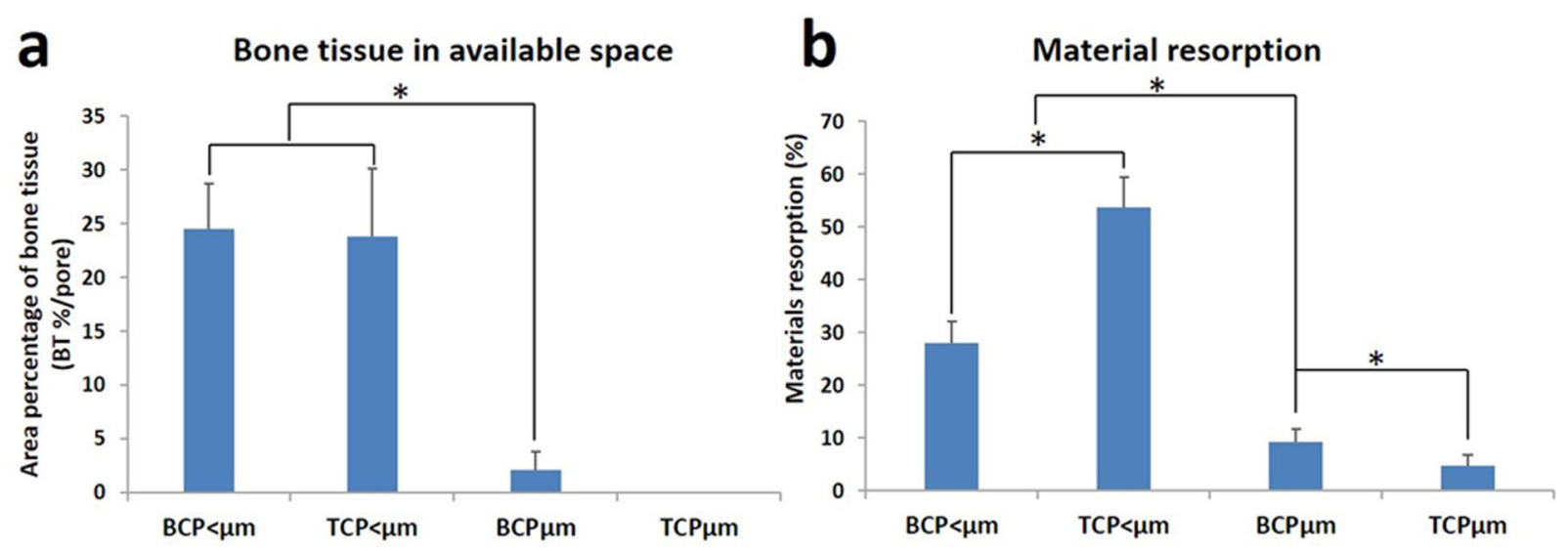

Fig. 6. Quantitative analyses of bone formation and material resorption. Quantitative histomorphometry data on (a) the area percentage of bone tissue in the available spaces and (b) the material resorption at 12 weeks post-operatively $\left({ }^{*} p<0.05\right)$. The Shapiro-Wilk normality test gave $p>0.05$, indicating normal distribution with a negative skewness of all data sets. 
enhances angiogenesis and triggers bone formation in ectopic defect sites (meeting abstract: Duan et al., ORS 2018 Annual Meeting: 0056).

Whether the specific surface topography could exert an indirect effect on bone formation was considered. Protein adsorption is often suggested as crucial in inductive bone formation (Ariizumi et al., 2013; Bolander et al., 2016; Webster et al., 2001), where osteoinduction of $\mathrm{CaP}$ materials is thought to be a secondary response following the adsorption of growth factors/cytokines from body fluids in vivo (Groot et al., 1998; Jin et al., 2009; Reddi et al., 2000). Since the function of growth factors/cytokines is dosedependent (Bonilla-Claudio et al., 2012; Hunziker et al., 2016), theoretically the more proteins concentrated in the implants should lead to higher osteoinductive potential. In the present study, $\mathrm{TCP}_{<\mu \mathrm{m}}$ adsorbed significantly more proteins from FBS per implant than $\mathrm{BCP}_{<\mu \mathrm{m}}$ (Fig. 2b,c and Table 1), while the latter triggered earlier bone formation than the former. Similarly, $\mathrm{BCP}_{u \mathrm{~m}}$ adsorbed similar or little more proteins than $\mathrm{TCP}_{\mu \mathrm{m}}$, but while the former triggered bone formation, the latter did not (Fig. 2b,c and Table 1). Therefore, it was concluded that the initiation and enhancement of inductive bone formation in $\mathrm{BCP}_{<\mu \mathrm{m}}$ and $\mathrm{TCP}_{<\mu \mathrm{m}}$ was less likely to be due to a larger surface area (and associated increased protein adsorption) but, more likely, instructed by the possible physical cues created by the smaller features in the surface topography.

It is important to consider which of the other effects of chemistry and surface feature morphology was most dominant in driving earlier bone formation in ectopic defects, as observed for $\mathrm{BCP}_{<\mu \mathrm{m}}$ (3-6 weeks) when compared to TCP ${ }_{<\mu m}\left(6-9\right.$ weeks). Firstly, $\mathrm{BCP}_{<\mu \mathrm{m}}$ consisted of $25 \% \mathrm{HA} / 75 \% \beta-\mathrm{TCP}$, while $\mathrm{TCP}_{<\mu \mathrm{m}}$ was phase-pure $\beta$-TCP. Although the role of chemical composition appears not to be an essential material factor to trigger inductive bone formation in CaP materials (Duan et al., 2017), it is generally thought that a higher content of TCP can affect the dissolution of $\mathrm{CaP}$ and, thus, the ion release (e.g. calcium and phosphate) from its surface. In turn, this increased ion release may enhance inductive bone formation (Chai et al., 2012; Habibovic et al., 2006; Nakamura et al., 2010; Shih et al., 2014; Yuan et al., 2006a; Yuan et al., 2006b). However, in the present study, $\mathrm{BCP}_{<u m}$ released less calcium ions in vitro than $\mathrm{TCP}_{<\mu \mathrm{m}}$ (Fig. $\left.2 \mathbf{a}\right)$ and resorbed at a slower rate than $\mathrm{TCP}_{<\mu \mathrm{m}}$ in vivo (Fig. $6 b)$. Therefore, the earlier trigger or enhancement of bone formation observed in the present study for $\mathrm{BCP}_{<\mu \mathrm{m}}$ seemed not to be attributed to the rate of calcium ion release.

Both BCP test materials had in vivo resorption rates between those observed for $\mathrm{TCP}_{<\mu \mathrm{m}}$ and $\mathrm{TCP}_{\mu \mathrm{m}}$ (Fig. $6 b)$, contrary to the general view that a higher TCP content would lead to a faster resorption. $\mathrm{BCP}_{\mu \mathrm{m}}$ had the lowest dissolution in vitro (Fig. 2a) but a faster rate of resorption as compared to $\mathrm{TCP}_{\mu \mathrm{m}}$ in vivo, indicating that cell-mediated resorption played a major role in the in vivo resorption of the BCP test articles. This was further corroborated by the histological analysis (Fig. $3 \mathbf{b}, \mathbf{c})$, in which multinucleated osteoclast-like cells were observed on the materials' surface. Whether chemistry could dictate the mechanism of resorption and indirectly drive earlier bone formation in $\mathrm{BCP}_{<\mu \mathrm{m}}$ was analysed, resulting not to be a dominant factor, since abundant resorption by multi-nucleated giant cells was also observed by histological analysis in $\mathrm{TCP}_{<\mu \mathrm{m}}$ (Fig. 3c). The slower resorption observed for $\mathrm{BCP}_{\mu \mathrm{m}}$ as compared to $\mathrm{BCP}_{<\mu \mathrm{m}}$ corroborated the findings of Davison et al. (2014b), according to which $\mathrm{CaP}$ ceramic with sub-micron-scaled surface structures favoured the formation of osteoclasts from mononuclear cells and facilitated material resorption as compared to its micron-scale structured counterpart. Therefore, according to the present study, if the presence of multinucleated osteoclastlike cells was a driver for osteoinductive potential, the size of the surface topography feature was more likely to be the dominant factor than the chemistry.

BCP and TCP families contained a different level of microporosity (Table 1). Microporosity determines the osteoinductive potential of CaP materials because it creates an ideal microenvironment for protein adsorption and/or cell attachment, differentiation and proliferation (Barba et al., 2017; Chan et al., 2012; Davison et al., 2014a; Duan et al., 2016; Duan et al., 2017; Yuan et al., 2010), where higher microporosity leads to higher osteoinductive potential (Chan et al., 2012). Since lower microporosity was detected in the BCP than in the TCP family, the trigger of earlier inductive bone formation observed in $\mathrm{BCP}_{<\mu \mathrm{m}}$ was not likely to be linked to microporosity.

Based on the study data and the supporting literature, the most dominant secondary factor (after surface feature size) for CaP driven osteoinductivity is the surface feature morphology of the substrate. In the present study, needle-shaped surface features gave rise to earlier bone formation than grainshaped surfaces. As chemistry is still likely to have a certain level of influence on osteoinductivity, the strength of effect was proposed to be as follows: surface feature size $>$ surface feature morphology $>$ substrate chemistry. The improved bone formation outcomes for $\mathrm{BCP}_{<\mu \mathrm{m}}$ and $\mathrm{BCP}_{\mu \mathrm{m}}$ in this intramuscular model indicated that they had higher osteoinductive potential than $\mathrm{TCP}_{<\mu \mathrm{m}}$ and $\mathrm{TCP}_{\mu \mathrm{m}}$, respectively. Previous studies show that osteoinductive materials facilitate bone regeneration in orthotopic skeletal sites as compared to non-osteoinductive materials (Duan et al., 2016; Yuan et al., 2010) and that a higher osteoinductive potential correlates with faster bone repair in orthotopic defects (Yuan et al., 2006a). Therefore, of all the articles tested in the study, $\mathrm{BCP}_{<\mu \mathrm{m}}$ may be expected to have good bone regeneration potential in clinical applications.

Using the current settings, the superiority of $\mathrm{BCP}_{<\mu \mathrm{m}}$ to the other 3 materials was demonstrated. However, besides the histological and histomorphometrical 
data, more analyses, such as quantitative $\mu \mathrm{CT}$, biochemical assays of bone-forming signals and immunohistostaining of bone markers, would make the conclusion stronger. Fluorescent labelling was used to monitor the onset of bone formation at different time points, without the need to include more animals in the study. Another approach could have been to use animal cohorts at each time point, which would allow for a more precise analysis and include bone quantity assessment at each time point. Finally, a clinically relevant animal study (i.e. orthotopic implantation) would be required to more accurately predict the potential clinical efficacy of these materials.

\section{Conclusions}

Evaluation of ectopic bone formation by two novel CaP materials with a needle-like surface topography showed that they could give rise to earlier and accelerated bone formation as compared to their counterparts with grain-like surface structures. Our data suggested that the relative strength of effect on osteoinductive potential was as follows: surface feature size $>$ surface feature morphology $>$ substrate chemistry. Of all the materials tested, $\mathrm{BCP}_{<\mu \mathrm{m}}$ with a needle-shaped surface topography was expected to have the best bone regeneration potential in clinical applications, although the performance of this material still needs to be evaluated in an orthotopic implantation site.

\section{Acknowledgements}

The authors would like to thank the Netherlands Institute for Regenerative Medicine (NIRM), the Rapid Prototyping of Custom-Made Bone-Forming Tissue Engineering Constructs (RAPIDOS Project, Ref. NMP-2013-EU-China, no. 604517), the Seventh Framework Programme of the European Union (no. 241879) and the Horizon 2020 Framework Programme (no. 674282) for their financial support. The authors also acknowledge financial support of Kuros Biosciences BV (the Netherlands) and Sichuan University (China) for the animal study and histological analysis.

\section{References}

Abagnale G, Steger M, Nguyen VH, Hersch N, Sechi A, Joussen S, Denecke B, Merkel R, Hoffmann B, Dreser A, Schnakenberg U, Gillner A, Wagner W (2015) Surface topography enhances differentiation of mesenchymal stem cells towards osteogenic and adipogenic lineages. Biomaterials 61: 316-326.
Acharya NK, Kumar RJ, Varma HK, Menon VK (2008) Hydroxyapatite-bioactive glass ceramic composite as stand-alone graft substitute for posterolateral fusion of lumbar spine: a prospective, matched, and controlled study. J Spine Disord Tech 12: 106-111.

Agarwal R, Singh V, Jurney P, Shi L, Sreenivasan S, Roy K (2013) Mammalian cells preferentially internalize hydrogel nanodiscs over nanorods and use shape-specific uptake mechanisms. Proc Natl Acad Sci 110: 17247-17252.

Ariizumi T, Ogose A, Kondo N, Kawashima H, Hotta T, Kudo N, Hoshino M, Inoue H, Irie H, Endo N (2013) The role of microstructure of highly purified beta-tricalcium phosphate for osteoinduction in canine dorsal muscles. J Biomater Nanobiotechnol 4: 189-193.

Barba A, Diez-Escudero A, Maazouz Y, Rappe K, Espanol M, Montufar EB, Bonany M, Sadowska JM, Guillem-Marti, Öhman-Mägi C, Persson C, Manzanares MC, Franch J, Ginebra MP (2017) Osteoinduction by foamed and 3D-printed calcium phosphate scaffolds: effect of nanostructure and pore architecture. ACS Appl Mater Interfaces 9: 4172241736.

Barradas AM, Yuan $\mathrm{H}$, van Blitterswijk CA, Habibovic P (2011) Osteoinductive biomaterials: current knowledge of properties, experimental models and biological mechanisms. Eur Cell Mater 21: 407-429.

Bolander J, Ji W, Geris L, Bloemen V, Chai YC, Schrooten J, Luyten FP (2016) The combined mechanism of bone morphogenetic protein- and calcium phosphate-induced skeletal tissue formation by human periosteum derived cells. Eur Cell Mater 31: 11-25.

Bonilla-Claudio M, Wang J, Bai Y, Klysik E, Selever J, Martin JF (2012) BMP signaling regulates a dosedependent transcriptional program to control facial skeletal development. Development 139: 709-719.

Chai YC, Roberts SJ, Desmet E, Kerckhofs G, van Gastel N, Geris L, Carmeliet G, Schrooten J, Luyten FP (2012) Mechanisms of ectopic bone formation by human osteoprogenitor cells on $\mathrm{CaP}$ biomaterial carriers. Biomaterials 33: 3127-3142.

Chan O, Coathup MJ, Nesbitt A, Ho CY, Hing, KA Buckland T, Campion C, Blunn GW (2012) The effects of microporosity on osteoinduction of calcium phosphate bone graft substitute biomaterials. Acta Biomater 8: 2788-2794.

Dalby MJ, Gadegaard N, Tare R, Andar A, Riehle MO, Herzyk P, Wilkinson CD, Oreffo RO (2007) The control of human mesenchymal cell differentiation using nanoscale symmetry and disorder. Nat Mater 6: 997-1003.

Dasgupta S, Auth T, Gompper G (2014) Shape and orientation matter for the cellular uptake of nonspherical particles. Nano Lett 14: 687-693.

Davison NL, Luo X, Schoenmaker T, Everts V, Yuan H, Barrère-de Groot F, de Bruijn JD (2014a) 
Submicron-scale surface architecture of tricalcium phosphate directs osteogenesis in vitro and in vivo. Eur Cell Mater 27: 281-297.

Davison NL, Gamblin AL, Layrolle P, Yuan H, de Bruijn JD, Barrère-de Groot F (2014b) Liposomal clodronate inhibition of osteoclastogenesis and osteoinduction by submicrostructured beta-tricalcium phosphate. Biomaterials 35: 5088-5097.

Davison NL, Su J, Yuan H, van den Beucken JJ, de Bruijn JD, Barrère-de Groot F (2015) Influence of surface microstructure and chemistry on osteoinduction and osteoclastogenesis by biphasic calcium phosphate discs. Eur Cell Mater 29: 314-329.

De Groot J (1998) Carriers that concentrate native bone morphogenetic protein in vivo. Tissue Eng 4: 337-341.

Duan R, Barbieri D, Luo X, Weng J, de Bruijn JD, Yuan H (2016) Submicron-surface structured tricalcium phosphate ceramics enhances the bone regeneration in canine spine environment. J Orthop Res 34: 1865-1873.

Duan R, Barbieri D, Luo X, Weng J, Bao C, de Bruijn JD, Yuan H (2017) Variation of bone forming ability with the physicochemical properties of calcium phosphate bone substitutes. Biomater Sci 6: 136-145.

Dupont S, Morsut L, Aragona M, Enzo E, Giulitti S, Cordenonsi M, Zanconato F, Le Digabel J, Forcato M, Bicciato S, Elvassore N, Piccolo S (2011) Role of YAP/ TAZ in mechanotransduction. Nature 474: 179-183.

Habibovic P, Yuan $H$, van der Valk CM, Meijer G, van Blitterswijk CA, de Groot K (2005) 3D microenvironment as essential element for osteoinduction by biomaterials. Biomaterials 26: 3565-3575.

Habibovic P, Sees TM, van den Doel MA, van Blitterswijk CA, de Groot K (2006) Osteoinduction by biomaterials-Physicochemical and structural influences. J Biomed Mater Res A 77: 747-762.

Habraken W, Habibovic P, Epple E, Bohner M (2016) Calcium phosphate in biomaterial applications: materials for the future? Materials Today 19: 69-87.

Hunziker EB, Jovanovic J, Horner A, Keel MJ, Lippuner K, Shintani N (2016) Optimisation of BMP-2 dosage for the osseointegration of porous titanium implants in an ovine model. Eur Cell Mater 32: 241256.

Italiani P, Boraschi D (2014) From monocytes to M1/M2 macrophages: phenotypical vs. functional differentiation. Front Immunol 5: 514. DOI: 10.3389/ fimmu.2014.00514.

Jin QM, Takita H, Kohgo T, Atsumi K, Itoh H, Kuboki Y (2000) Effects of geometry of hydroxyapatite as a cell substratum in BMP-induced ectopic bone formation. J Biomed Mater Res 52: 491-499.

Kilian KA, Bugarija B, Lahn BT, Mrksich M (2010) Geometric cues for directing the differentiation of mesenchymal stem cells. Proc Natl Acad Sci USA 107: 4872-4877.

Kolhar P, Anselmo AC, Gupta V, Pant K, Prabhakarpandian P, Ruoslahti E, Mitragotri S
(2013) Using shape effects to target antibody-coated nanoparticles to lung and brain endothelium. Proc Natl Acad Sci USA 110: 10753-10758.

Kolind K, Kraft D, Bøggild T, Duch M, Lovmand J, Pedersen FS, Bindslev DA, Bünger CE, Foss M, Besenbacher F (2014) Control of proliferation and osteogenic differentiation of human dental-pulpderived stem cells by distinct surface structures. Acta Biomater 10: 641-650.

LeGeros RZ (2008) Calcium phosphate-based osteoinductive materials. Chem Rev 108: 4742-4753. Loi F, Córdova LA, Zhang R, Pajarinen J, Lin TH, Goodman SB, Yao Z (2016) The effects of immunomodulation by macrophage subsets on osteogenesis in vitro. Stem Cell Res Ther 7: 15. DOI: 10.1186/s13287-016-0276-5.

Metavarayuth K, Sitasuwan P, Zhao X, Lin Y, Wang Q (2016) Influence of surface topographical cues on the differentiation of mesenchymal stem cells in vitro. ACS Biomater Sci Eng 2: 142-151.

Mitragotr S, Lahann J (2009) Physical approaches to biomaterial design. Nat Mater 8: 15-23.

Miyazaki M, Tsumura H, Wang JC, Alanay A (2009) An update on bone substitutes for spinal fusion. Eur Spine J 18: 783-799.

Nakamura S, Matsumoto T, Sasaki J, Egusa H, Lee KY, Nakano T, Sohmura T, Nakahira A (2010) Effect of calcium ion concentrations on osteogenic differentiation and hematopoietic stem cell nicherelated protein expression in osteoblasts. Tissue Eng Part A 16: 2467-2473.

Oh S, Brammer KS, Li YS, Teng D, Engler AJ, Chien S, Jin S (2009) Stem cell fate dictated solely by altered nanotube dimension. Proc Natl Acad Sci 106: 2130-2135.

Pollick S, Shors EC, Holmes RE, Kraut RA (1995) Bone formation and implant degradation of coralline porous ceramics placed in bone and ectopic sites. J Oral Maxillofac Surg 53: 915-922.

Reddi AH (2000) Morphogenesis and tissue engineering of bone and cartilage: inductive signals, stem cells, and biomimetic biomaterials. Tissue Eng 6: 351-359.

Ripamonti U (1991) Bone induction in nonhuman primates. an experimental study on the baboon. Clin Orthop Relat Res 269: 284-294.

Ross AM, Jiang Z, Bastmeyer M, Lahann J (2012) Physical aspects of cell culture substrates: topography, roughness, and elasticity. Small 8: 336355.

Samavedi S, Whittington AR, Goldstein AS (2013) Calcium phosphate ceramics in bone tissue engineering: a review of properties and their influence on cell behavior. Acta Biomater 9: 8037-8045.

Shih YR, Hwang Y, Phadke A, Kang H, Hwang NS, Caro EJ, Nguyen S, Siu M, Theodorakis EA, Gianneschi NC, Vecchio KS, Chien S, Lee OK, Varghese S (2014) Calcium phosphate-bearing matrices induce osteogenic differentiation of stem cells through adenosine signaling. Proc Natl Acad Sci USA 111: 990-995. 
Spiller KL, Freytes DO, Vunjak-Novakovic G (2015) Macrophages modulate engineered human tissues for enhanced vascularization and healing. Ann Biomed Eng 43: 616-627.

Phadke A, Hwang Y, Kim SH, Kim SH, Yamaguchi T, Masuda K, Varghese S (2013) Effect of scaffold microarchitecture on osteogenic differentiation of human mesenchymal stem cells. Eur Cell Mater 25: 114-129.

Webster TJ, Schadler LS, Siegel RW, Bizios R (2001) Mechanism of enhanced osteoblast adhesion on nanophase alumina involve vitronectin. Tissue Eng 7: 291-301.

Yamasaki H, Sakai H (1992) Osteogenic response to porous hydroxyapatite ceramics under the skin of dogs. Biomaterials 13: 308-312.

Yuan H, Kurashina K, de Bruijn JD, Li Y, de Groot K, Zhang X (1999) A preliminary study on osteoinduction of two kinds of calcium phosphate ceramics. Biomaterials 20: 1799-1806.

Yuan H, van Blitterswijk CA, de Groot K, de Bruijn JD (2006a) A comparison of bone formation in biphasic calcium phosphate (BCP) and hydroxyapatite (HA) implanted in muscle and bone of dogs at different time periods. J Biomed Mater Res Part A 78: 139-147.

Yuan H, van Blitterswijk CA, de Groot K, de Bruijn JD (2006b) Cross-species comparison of ectopic bone formation in biphasic calcium phosphate (BCP) and hydroxyapatite (HA) scaffolds. Tissue Eng 12: 16071615.

Yuan H, Fernandes H, Habibovic P, de Boer J, Barradas AM, de Ruiter A, Walsh WR, van Blitterswijk CA, de Bruijn JD (2010) Osteoinductive ceramics as a synthetic alternative to autologous bone grafting. Proc Natl Acad Sci USA 107: 13614-13619.

Zhang J, Dalbay MT, Luo X, Vrij E, Barbieri D, Moroni L, de Bruijn JD, van Blitterswijk CA, Chapple JP, Knight MM, Yuan H (2017) Topography of calcium phosphate ceramics regulates primary cilia length and TGF receptor recruitment associated with osteogenesis. Acta Biomater 57:487-497.

Zhang X, Zhou P, Zhang J, Chen W, Wu C (1991) A study of porous block of HA ceramics and its osteogenesis. In: A Ravaglioli, A Krajewski edition, Bioceramics and the human body, Elsevier Science, Amsterdam; 408-415.

\section{Discussion with Reviewers}

Bill Walsh: Can the authors provide further information regarding the multinucleated cell populations versus the materials?

Authors: As described in the Results section, $\mathrm{BCP}_{<\mu \mathrm{m}}$ was the material most colonised by multinucleated cells and triggered the earliest bone formation, followed by $\mathrm{TCP}_{<\mu \mathrm{m}}$. In contrast, $\mathrm{BCP}_{\mu \mathrm{m}}$ was sporadically colonised by multinucleated cells and triggered limited bone formation, while multinucleated cells were absent on $\mathrm{TCP}_{\mu \mathrm{m}}$ and no bone formed. This suggested a relation between multinucleated cells and material-directed bone formation. Moreover, Duan et al. (2018; meeting abstract: ORS 2018 Annual Meeting: 0056) report that CaP materials with micron surface topography displayed more M1 macrophage formation, as indicated by the enhanced TNF- $\alpha$ and IL- $1 \beta$ secretion, while sub-micron surface topographic CaP materials facilitated more M2 phenotype macrophages polarisation, as shown by the larger production of TGF- $\beta$ and CCL18. These materials enhanced angiogenesis and triggered ectopic bone formation.

Bill Walsh: Could anatomical site play a role?

Authors: Yes, the osteoinduction potential of biomaterials is influenced by the anatomical site in which the material is implanted. For example, Habibovic et al. (2006) report that no bone is formed after 4 months of subcutaneous implantation of a BCP in goats, whereas bone is induced intramuscularly in 7 out of 10 implants in the same animals. Zhi et al. (2014, additional reference) report that hydroxyapatite scaffolds induce faster osteogenesis in dorsal muscles as compared to those placed in abdominal cavities after 6 months of implantation. Zhang et al. (2012, additional reference) show that porous hydroxyapatite implanted close by the femur give the most bone formation, followed by those implanted in the vastus lateralis muscle and peritoneum, while those implanted in the omentum do not trigger new bone formation after 6 months post-operatively. In previous studies, materials are implanted in paraspinal muscle pockets, with reproducible results (Davison et al., 2014a; Duan et al., 2016; Duan et al., 2017; Yuan et al., 2010; Zhang et al., 2014, additional reference). In the present study, the tested materials were implanted according to a random scheme in paraspinal muscle pouches of beagles and each side of the animal received 2 implants. Therefore, no differences in the biological response were expected.

Hannu Aro: This was an EU-funded project. What was the reason to execute the animal experiment outside Europe?

Authors: The study was funded by the EU only in part (in specific, the development and characterisation of novel materials), which did not include animal studies. The in vivo aspects were funded by Kuros Biosciences (the Netherlands) and Sichuan University (China). Due to the link with China, as well as lower animal study costs, it was decided to perform the in vivo studies in a certified animal care facility in China (Chengdu Dossy Experimental Animals Co. Ltd., Sichuan, China).

Hannu Aro: Are the authors planning to repeat the experiment in a time-sequence manner?

Authors: Currently, there are no plans to repeat the experiment in a time-sequence manner as the use 
of fluorescent labelling allowed the revealing of the dynamics of bone formation at earlier time points (3, 6 and 9 weeks). The results showed that BCP $<1 \mu \mathrm{m}$ triggered bone formation between 3 and 6 weeks, whereas the onset of bone formation was between 6 and 9 weeks for TCP $<1 \mu \mathrm{m}$. The focus of future studies will shift towards evaluating the materials in more clinically relevant animal models, such as rabbit or sheep posterolateral spinal fusion.

Hannu Aro: In clinical practice, it is commonly referred to the radiographically visible new bone when talking about the efficacy of bone graft substitutes. Also, in experimental studies, it would be desirable to see radiographic quantification (such as $3 \mathrm{D}-\mu \mathrm{CT}$ ) of new bone formation and not only histomorphometry of new bone. Would the authors comment the issue?

Authors: Histomorphometry is a more accurate method to quantify bone formation (and implant resorption) than radiographic techniques - especially with CaP-based bone graft materials - since it is difficult to distinguish bone from (residual) $\mathrm{CaP}$ by radiography, as this technique is based on grey-scale levels. The draw-back of histomorphometry is that it is often only based on 2D slides and, hence, many samples needs to be evaluated to reduce inaccuracy. This is not the case for $3 \mathrm{D}-\mu \mathrm{CT}$ analysis. With their advantages and disadvantages, both techniques provide valuable analysis when used in combination.

\section{Additional references}

Zhang C, Huang P, Weng J, Zhi W, Hu Y, Feng H, Yao Y, Li S, Xia T (2012) Histomorphological researches on large porous hydroxyapatite cylinder tubes with polylactic acid surface coating in different nonskeletal sites in vivo. J Biomed Mater Res A 100:1203-1208.

Zhang J, Luo X, Barbieri D, Barradas AM, de Bruijn JD, van Blitterswijk CA, Yuan H (2014) The size of surface microstructures as an osteogenic factor in calcium phosphate ceramics. Acta Biomater 10: 32543263.

Zhi W, Zhang C, Duan K, Li X, Qu S, Wang J, Zhu Z, Huang P, Xia T, Liao G, Weng J (2014) A novel porous bioceramics scaffold by accumulating hydroxyapatite spherulites for large bone tissue engineering in vivo. II. Construct large volume of bone grafts. J Biomed Mater Res A 102: 2491-501.

Editor's note: The Scientific Editor responsible for this paper was Chris Evans. 